\title{
Heavy metal pollution among autoworkers. I. Lead
}

\author{
J. CLAUSEN ${ }^{1}$ AND S. C. RASTOGI ${ }^{2}$ \\ From the Institute of Hygiene, Preventive and Social Medicine, Odense University, Odense, Denmark
}

ABSTRACT Lead pollution was evaluated in 216 individuals working in 10 garages on the Island of Funen, Denmark and related to data from biochemical and medical examinations. Clinical symptoms were recorded by means of a questionnaire. Increased blood lead levels were found in $59 \%$, with $9 \%$ having above $80 \mu \mathrm{g}$ lead/100 ml (3.86 $\mu \mathrm{mol} / \mathrm{l})$ whole blood. Mechanics in eight out of ten garages had significantly increased blood lead levels. A decrease in $\delta$-aminolevulinic acid dehydratase (ALAD) activity was associated with increased blood lead levels but the latter were not related to haematological changes, tobacco consumption or to length of service in the trade. Particulate lead air pollution was not the sole cause of increased blood lead levels. Raised lead values were maximal among diesel engine workers who are exposed to high pressure-resistant lubricants containing lead naphthenate. As these workers complained of skin damage, lead absorption may have occurred through the skin. Assay of lead content showed $9290 \mathrm{ppm}$ in gear oil and 1500-3500 ppm in used motor oils. The data are discussed in relation to the occupational risks in auto repair shops.

The use of automobiles has increased during the last 25 years and the result has been a rising number of service stations and repair shops (autoworkshops). Furthermore, in Europe there has been an increase in the use of leaded petrol. Lead present in motor exhaust gases may be one of the major sources of environmental lead pollution (Danielson, 1967; Schroeder and Tipton, 1968; Barltrop, 1969; Goyer, 1971; Hicks, 1972; Institute of Petroleum 1972; Goyer and Phyne, 1973). A population exposed to lead may have higher blood lead levels than an unexposed population (Ludwig et al., 1965; Department of Public Health, California, 1967; Thomas et al., 1967; Hammond, 1969).

Subjective complaints from those employed in autoworkshops (autoworkers), mainly mechanics, led us to attempt a systematic occupational and epidemiological study of this group of workers. Although it is recognised that they are exposed to various types of hazardous chemicals, priority was given to lead because of the many sources of lead in this industry, for example lead in petrol and motor exhaust gas, lead-containing lubricants and grease

Received for publication 1 June 1976

Accepted for publication 2 March 1977

${ }^{1}$ Present address: Laboratory of Biochemistry and Toxicology Institute of Life Science Faculty Natural Sciences, Building 161, University of Roskilde, Roskilde, Denmark.

${ }^{2}$ Present address: The Neurochemical Institute, 58, Rådmandsgade, DK 2200 Copenhagen N, Denmark. (lead naphthenate), paints, and lead given off during the process of welding. Estimation of other heavy metals (cadmium, copper, chromium, nickel, manganese) described in Part II (pages 216-219).

\section{Material and methods}

EXPOSED AND CONTROL SUBJECTS

216 employees in 10 autoworkshops from the Funen area of Denmark were studied. They were divided into groups comprising 106 mechanics, 32 apprentice mechanics, 13 platesmiths and welders (metal workers) 16 painters and 49 miscellaneous workers including clerical staff, warehousemen and workmen (Table 1). Blood samples randomly collected from donors to the Blood Bank of Odense County Hospital, and laboratory personnel were used for control purposes. None of the control subjects was employed in the accumulator, garage or metal industry. These 31 men and 23 women matched the autoworkers with regard to age.

STAFF INTERVIEW AND MEDICAL

EXAMINATION

The interview enabled the staff to give a detailed description of past and present occupations (including training), materials handled during their work, smoking and drinking habits and finally, their symptoms in relation to different organs. The blood 
Table 1 Classification of subjects

\begin{tabular}{lrl}
\hline Subject & Total & $\begin{array}{l}\text { Age group } \\
\text { (years) }\end{array}$ \\
\hline Controls & & \\
$\quad$ Male & 31 & $21-71$ \\
Female & 23 & $21-73$ \\
& & \\
Staff of autoworkshops & & \\
Mechanics & 106 & $17-68$ \\
Apprentice mechanics & 32 & $16-25$ \\
Smiths and welders & 13 & $22-63$ \\
$\quad$ Painters & 16 & $16-65$ \\
Miscellaneous workers: & & \\
$\quad$ Precision mechanics & 1 & 47 \\
$\quad$ Electricians & 8 & $24-45$ \\
Greasers and service men & 23 & $20-58$ \\
Sundry apprentices & 7 & $16-21$ \\
Office workers: & & \\
$\quad$ Male & 5 & $28-49$ \\
$\quad$ Female & 5 & $20-64$ \\
\hline
\end{tabular}

pressure was measured three times and the lowest value was recorded. The figures obtained were compared with the lower limit of $160 / 95 \mathrm{mmHg}$ for blood pressure in hypertension (World Health Organization, 1962). This limit for hypertension corresponds well with the mean value of systolic blood pressure of $137 \pm 19 \mathrm{mmHg}$ in Danish men (Hagerup, 1974).

\section{BIOCHEMICAL ASSAYS}

Assay of $\delta$-aminolevulinic acid dehydratase (ALAD) activity and lead content in whole blood and determination of $\delta$-aminolevulinic acid (ALA) in urine have been described previously (Melgaard et al., 1976a). Lead in dust and oil samples (about $30 \mathrm{mg}$ ) was extracted by heating them twice to $100^{\circ} \mathrm{C}$ for two hours with $2 \mathrm{ml}$ concentrated hydrochloric acid-nitric acid $(1: 1)$ mixture. Lead in the extracts was determined by flameless atomic absorption spectrophotometry at $283 \cdot 3 \mathrm{~nm}$. The method of standard additions was employed to draw a standard curve. Haematological examination of blood, and serum enzyme assays were routinely carried out in the Clinical Chemistry Department at Odense Hospital.

COLLECTION AND ANALYSIS OF AIR SAMPLES EEC-recommended equipment for the determination of ambient air pollution was used. Approximately $1000 \mathrm{~m}^{3}$ air was sucked in at various points, at a height of $2.5 \mathrm{~m}$, through Whatman Glass Filter paper Type GF/A, which can retain particles over $1.5 \mu \mathrm{m}$ in diameter.
STATISTICAL METHODS

Because distribution of data was non-Gaussian, Wilcoxon's test (Documenta Geigy, 1962) was used to detect significant differences between groups of data. Spearman's rank correlation test (Documenta Geigy, 1962) was carried out to establish the correlation between lead and ALAD levels in blood. Groups of data are presented as mean and median values together with their $5 \%$ and $95 \%$ quartiles.

The quantitative relationship between lead and ALAD levels in blood was analysed by the $2 \times 2$ table method of Zielhuis and Verberk (1974).

\section{Results}

The heavy metal content and ALAD activity of whole blood from the control group has been previously defined (Melgaard et al., 1976a). The lead content and ALAD activity in the blood of autoworkers is shown in Table 2. Figs. 1 and 2 show ALAD activity as a function of blood levels in normal subjects and autoworkers respectively. Spearman's rank analysis showed that there was a significant correlation between the lead level and ALAD activity in blood from both the groups $(P<0.001)$. The ALAD activity in the blood of autoworkers was depressed as a result of the higher blood lead levels (ALAD: $1097 \pm 309 \mu \mathrm{mol}$ $\mathrm{PBG} / \mathrm{h} / \mathrm{l} \mathrm{RBC}$ in control subjects and $695 \pm 295$ $\mu \mathrm{mol} \mathrm{PBG} / \mathrm{h} / \mathrm{l} \mathrm{RBC}$ in autoworkers).

The lead levels in whole blood of all autoworkers was significantly higher than that of control subjects (Wilcoxon's test $P<0.002$ ). The mean values were respectively $44 \cdot 8 \pm 22 \cdot 8 \mu \mathrm{g} / 100 \mathrm{ml}(2 \cdot 16 \pm 1 \cdot 10$ $\mu \mathrm{mol} / \mathrm{l})$ and $18.6 \pm 9.6 \mu \mathrm{g} / 100 \mathrm{ml}(0.90 \pm 0.46$ $\mu \mathrm{mol} / 1)$. Nine per cent of the autoworkers had a blood lead level above the acceptable biological limit (80 $\mu \mathrm{g} / 100 \mathrm{ml}, 3 \cdot 86 \mu \mathrm{mol} / \mathrm{l})$. Taking mechanics as a special group, $52 \%$ showed a blood lead level significantly higher than that of control subjects $(\mathrm{P}<$ 0.01 , Wilcoxon's test). Among other groups within our survey metal workers (smiths) and painters also showed significantly higher values for blood lead (P $<0.01$, Wilcoxon's test), while the clerical staff had normal values. A comparison of median and mean values of different occupational groups is indicated in Table 2. Whereas the mean and median values of the controls were identical (within the $5 \%$ limit) both the median and the mean values of whole blood lead of mechanics was more than twice the normal mean. Blood lead levels in autoworkers were neither related to their tobacco consumption (number of tobacco years), nor to the length of their service in the trade. 
Table 2 ALAD activity and lead content of blood of controls and autoworkers

\begin{tabular}{|c|c|c|c|c|c|c|c|c|c|c|c|c|}
\hline \multirow[t]{3}{*}{ Subject } & \multirow{2}{*}{\multicolumn{2}{|c|}{$\begin{array}{l}A L A D \text { activity } \\
(\mu \mathrm{mol} P B G / h / I R B C)\end{array}$}} & \multicolumn{10}{|c|}{ Lead in whole blood } \\
\hline & & & \multicolumn{5}{|l|}{$(\mu \mathrm{g} / 100 \mathrm{ml})$} & \multicolumn{5}{|l|}{ ( $\mu \mathrm{mol} /$ litre) } \\
\hline & Mean & $S D^{*} \quad S E$ & Mean $S D^{*}$ & $S E$ & Median & $5 \% Q$ & $95 \% Q$ & Mean $S D^{*}$ & $S E$ & Median & $5 \% Q$ & $95 \% Q$ \\
\hline \multicolumn{13}{|l|}{ Normal: } \\
\hline Men & 976 & $\begin{array}{l} \pm 52 \pm 288 \\
(452-1282)\end{array}$ & $\begin{array}{l}23 \cdot 4 \pm 1 \cdot 7 \\
(11 \cdot 5-46 \cdot 0)\end{array}$ & $\pm 9 \cdot 4$ & $24 \cdot 2$ & $9 \cdot 5$ & $28 \cdot 5$ & $\begin{array}{l}1 \cdot 1 \pm 0 \cdot 1 \\
(0 \cdot 6-2 \cdot 2)\end{array}$ & $\pm 0 \cdot 5$ & $1 \cdot 2$ & $0 \cdot 5$ & $1 \cdot 4$ \\
\hline Women & 1189 & $\begin{array}{l} \pm 77 \pm 368 \\
(670-1713)\end{array}$ & $\begin{array}{l}12 \cdot 1 \pm 1 \cdot 1 \\
(2 \cdot 5-32 \cdot 0)\end{array}$ & $\pm 5 \cdot 2$ & $12 \cdot 5$ & $7 \cdot 5$ & $22 \cdot 3$ & $\begin{array}{l}0.6 \pm 0.1 \\
(0 \cdot 1-1 \cdot 5)\end{array}$ & $\pm 0 \cdot 3$ & 0.6 & 0.4 & $1 \cdot 1$ \\
\hline Mean of both sexes & 1079 & \pm 309 & $\begin{array}{l}18 \cdot 6 \\
\pm 9 \cdot 6\end{array}$ & & $20 \cdot 5$ & $7 \cdot 2$ & $29 \cdot 6$ & $\begin{array}{l}0.90 \\
\pm 0.5\end{array}$ & & $1 \cdot 0$ & 0.3 & $1 \cdot 4$ \\
\hline \multicolumn{13}{|l|}{ Autoworkers: } \\
\hline (all) & 695 & \pm 295 & $\begin{array}{l}44 \cdot 8 \pm 22 \cdot 8 \\
(2 \cdot 4-125)\end{array}$ & & $29 \cdot 5$ & $13 \cdot 0$ & $87 \cdot 0$ & $\begin{array}{l}2 \cdot 2 \pm 1 \cdot 1 \\
(0 \cdot 1-6 \cdot 0)\end{array}$ & & $1 \cdot 4$ & 0.6 & $4 \cdot 2$ \\
\hline Mechanics & & & $\begin{array}{l}44 \cdot 6 \pm 29 \cdot 8 \\
(11 \cdot 0-125)\end{array}$ & & $41 \cdot 0$ & $11 \cdot 1$ & $81 \cdot 5$ & $\begin{array}{l}2 \cdot 2 \pm 1 \cdot 4 \\
(0 \cdot 5-6 \cdot 0)\end{array}$ & & $2 \cdot 0$ & 0.5 & $3 \cdot 9$ \\
\hline Apprentice mechanics & & & $\begin{array}{l}40 \cdot 0 \pm 25 \cdot 6 \\
(50.78)\end{array}$ & & $31 \cdot 4$ & $13 \cdot 5$ & $72 \cdot 0$ & $\begin{array}{l}1 \cdot 9 \pm 1 \cdot 2 \\
(0 \cdot 2-3 \cdot 8)\end{array}$ & & $1 \cdot 5$ & 0.7 & $3 \cdot 5$ \\
\hline Smiths & & & $\begin{array}{l}38 \cdot 3 \pm 19 \cdot 1 \\
(2 \cdot 4-89 \cdot 0)\end{array}$ & & $34 \cdot 8$ & $3 \cdot 9$ & $53 \cdot 0$ & $\begin{array}{l}1.9 \pm 0.9 \\
(0 \cdot 1-4 \cdot 3)\end{array}$ & & $1 \cdot 7$ & 0.2 & $2 \cdot 6$ \\
\hline Painters & & & $\begin{array}{l}42 \cdot 8 \pm 22 \cdot 3 \\
(8 \cdot 1-97 \cdot 5)\end{array}$ & & $32 \cdot 7$ & $10 \cdot 8$ & $92 \cdot 5$ & $\begin{array}{l}2 \cdot 1 \pm 1 \cdot 1 \\
(0 \cdot 4-4 \cdot 7)\end{array}$ & & $1 \cdot 6$ & 0.5 & $4 \cdot 5$ \\
\hline Miscellaneous workers & & & $\begin{array}{l}42 \cdot 0 \pm 17 \cdot 2 \\
(13 \cdot 0-92 \cdot 5)\end{array}$ & & $37 \cdot 7$ & $13 \cdot 5$ & $83 \cdot 0$ & $\begin{array}{l}2 \cdot 0 \pm 0.8 \\
(0 \cdot 6-4 \cdot 5)\end{array}$ & & $1 \cdot 8$ & 0.7 & $4 \cdot 0$ \\
\hline
\end{tabular}

Range in parentheses

SD* values are only indicative because of non-Gaussian distribution. $Q=$ quartile

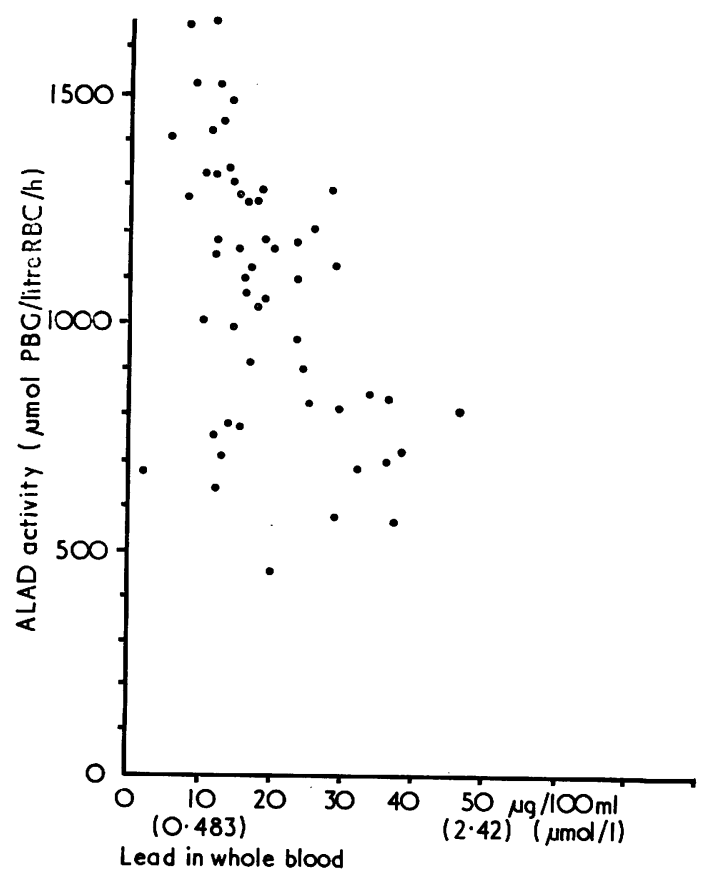

Fig. 1 Relationship between lead in whole blood and ALAD activity in normal subjects. (n = 57; Spearman's correlation coefficient $\mathrm{r}=0.4694 ; \mathrm{P}<0.001)$.

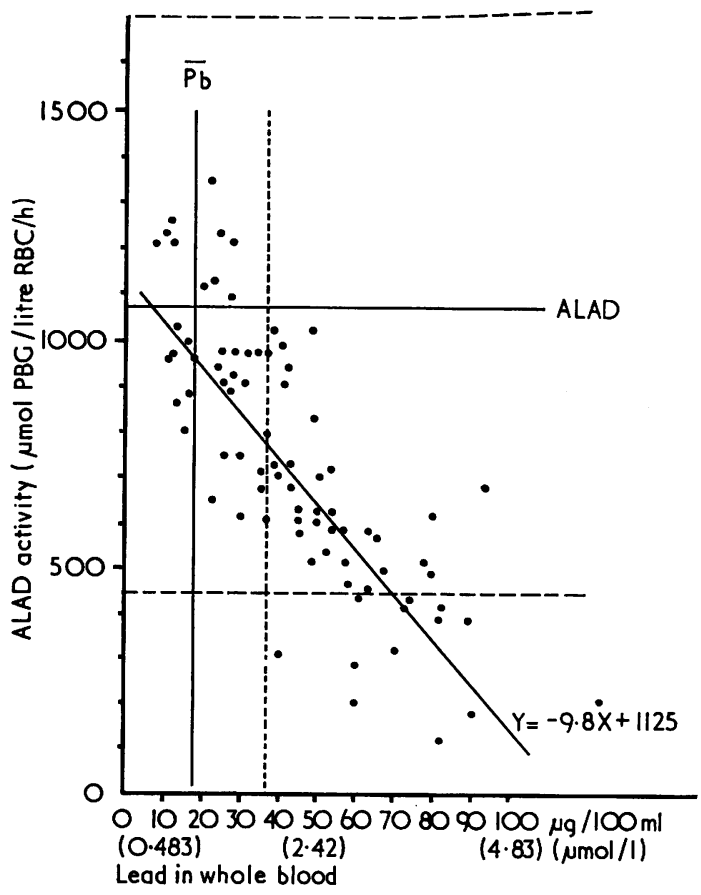

Fig. 2 The relationship between lead in whole blood and $A L A D$ activity in workers at garages (auto repairshops $)$. $(\mathrm{n}=96 ;$ Spearman's correlation coefficient $\mathrm{r}=0.7850 ; \mathrm{P}<0.001)$. 
Table 3 Lead content in the air of various workshops

\begin{tabular}{|c|c|c|c|}
\hline Workshops & Total no. of samples & $\begin{array}{l}\text { Dust content } \\
\left(\mu \mathrm{g} / \mathrm{m}^{3} \text { air }\right)\end{array}$ & $\begin{array}{l}\text { Lead content } \\
\left(\mu \mathrm{g} / \mathrm{m}^{3} \text { air }\right)\end{array}$ \\
\hline Autoworkshops & 17 & $\begin{array}{l}119 \cdot 8 \pm 47 \cdot 6 \\
(54 \cdot 6-234 \cdot 6)\end{array}$ & $\begin{array}{l}3 \cdot 19 \pm 2 \cdot 29 \\
(0 \cdot 2-9 \cdot 2)\end{array}$ \\
\hline Plate workshop & 4 & $\begin{array}{l}367 \cdot 5 \pm 165 \cdot 5 \\
(224 \cdot 0-642 \cdot 0)\end{array}$ & $\begin{array}{l}3 \cdot 8 \pm 0 \cdot 95 \\
(2 \cdot 4-5 \cdot 1)\end{array}$ \\
\hline Paint workshops & 3 & $\begin{array}{r}378 \cdot 5 \\
2995 \cdot 0 \\
123 \cdot 6\end{array}$ & $\begin{array}{r}2 \cdot 7 \\
35 \cdot 5 \\
0.9\end{array}$ \\
\hline Outside the workshops & 8 & $\begin{array}{l}76 \cdot 8 \pm 49 \cdot 9 \\
(29 \cdot 3-185 \cdot 5)\end{array}$ & $\begin{array}{l}0.9 \pm 0.7 \\
(0 \cdot 2-2 \cdot 2)\end{array}$ \\
\hline
\end{tabular}

Range in parentheses

The comparison of mean blood lead levels of mechanics in the ten different garages, showed that the workers in eight of these garages had significantly increased mean blood lead levels. The two workshops with normal mean lead levels were a state-owned bus repairing workshop and a small privately owned firm.

Table 3 shows dust and particulate lead content in the air in various rooms and in the ambient air outside the workshops. Variation in the amount of dust as well as in lead content was observed in the air of different workshops.

The lead burden may also originate from petrol, gear oils, grease and lubricants, from skin absorption; oils used in the autoworkshops were therefore assayed for their lead content. Table 4 shows the

Table 4 Lead content ${ }^{*}$ of various unused and used oils

\begin{tabular}{|c|c|c|c|}
\hline \multicolumn{3}{|l|}{$\begin{array}{c}\text { Unused oils } \\
\text { Oil type }\end{array}$} & $\begin{array}{l}\text { Lead content } \\
(p p m)\end{array}$ \\
\hline \multicolumn{3}{|c|}{$\begin{array}{l}\text { Mobil Oil 46-SAE-90 Gear oil } \\
\text { Motor Oil Motor cleaner } \\
\text { Motor Oil FK Tyre cleaner } \\
\text { Mobil Oil Super 10 W 50 } \\
\text { Mobil Oil Special Oil 10-SAE-40 } \\
\text { Mobil Oil code No. 80-90 } \\
\text { Mobil Oil code No. } 2023 \\
\text { Melkylen cleaner Perfection A/S } \\
\text { Brake-washing oil } \\
\text { Hydraulic Oil (Mobil Oil) } \\
\text { Lockheed Brake Oil Univs. Series 329S }\end{array}$} & $\begin{array}{r}9279 \cdot 6 \\
18 \cdot 7 \\
11 \cdot 0 \\
14 \cdot 9 \\
4 \cdot 6 \\
6 \cdot 2 \\
9 \cdot 3 \\
13 \cdot 3 \\
2 \cdot 1 \\
24 \cdot 5\end{array}$ \\
\hline $\begin{array}{l}\text { Used oils } \\
\quad \text { Car type }\end{array}$ & Oil used & $\begin{array}{l}\text { Motor } \\
\text { driven } \\
(\mathrm{km})\end{array}$ & $\begin{array}{l}\text { Lead content } \\
(p p m)\end{array}$ \\
\hline $\begin{array}{l}\text { Ford Cortina } 1969 \\
\text { Renault 4, } 1973 \\
\text { Mascot } 1965 \\
\text { Datsun } 1973 \\
\text { Ford Taunus } 1300 \\
\quad 1971 \\
\text { Volvo } 142,1973\end{array}$ & $\begin{array}{l}\text { Gulf Multi-G 20-50 } \\
\text { Chevron (type?) } \\
\text { Mobil Special SAE } \\
10 \text { W } 50 \\
\text { Mobil Special SAE } \\
10 \text { W } 50 \\
\text { Esso } \\
\text { Uniflow SAE } 10 \text { W } \\
\text { Shell Spiras } \\
\text { Gear Oil HD } 80\end{array}$ & $\begin{array}{r}1600 \\
04500 \\
5500\end{array}$ & $\begin{array}{r}1455 \cdot 6 \\
3437 \cdot 8 \\
696 \cdot 5\end{array}$ \\
\hline
\end{tabular}

* = assayed in triplicate lead concentration in some used and unused oils employed in the autoworkshops. Gear oil was found to contain $9280 \mathrm{ppm}$ lead and various used motor oils contained between 1500 and 3500 ppm lead.

Abnormal haematological findings among autoworkers (Table 5) were more often encountered among mechanics and their apprentices. Abnormal haematological findings were in a few cases related to high lead levels in the blood. None of the autoworkers had an erythrocyte count or haemoglobin concentration which was abnormal.

High blood pressure (over 160/95) was found in $37 \%$ of the mechanics, $7 \%$ apprentice mechanics and $18 \%$ of the miscellaneous workers. Fourteen per cent of mechanics showed increased serum bilirubin and thymol reaction and $11 \%$ of mechanics had raised serum AlT (alanine aminotransferase; SGPT), serum AsT (aspartate aminotransferase; SGOT) and lactate dehydrogenase enzyme levels in the serum. Twelve per cent of mechanics and $9 \%$ of apprentice mechanics had raised serum alkaline phosphatase levels. A few workers in other groups also had these abnormalities.

Thirty-seven per cent of autoworkers had urinary ALA levels between $4 \cdot 5-10 \mathrm{mg} / 1$ (34.33-76.3 $\mu \mathrm{mol} / \mathrm{l})$, $10 \%$ above $10 \mathrm{mg} / \mathrm{l}$ and the remainder below $4.5 \mathrm{mg} / \mathrm{l}$. Four autoworkers had a reduced blood leucocyte count.

Autoworkers' symptoms are shown in Table 6. Symptoms relating to the central nervous system were encountered more often among painters than in metal workers (smiths, plate fitters and welders), mechanics or their apprentices. Twenty-nine per cent of the mechanics complained of skin rash on the arms and hands. Only a few had tremor of the hands and digital paraesthesiae. The relationship between high blood lead levels and skin rash is shown in Table 7. As raised serum transaminase attributable to increased lead burden has been reported (de Bruin, 1971), Table 7 relates transaminase to blood lead levels. Only $14 \%$ and $2 \%$ of the auto- 
Table 5 Relation between lead content and abnormal haematological findings in whole blood of autorepair workers

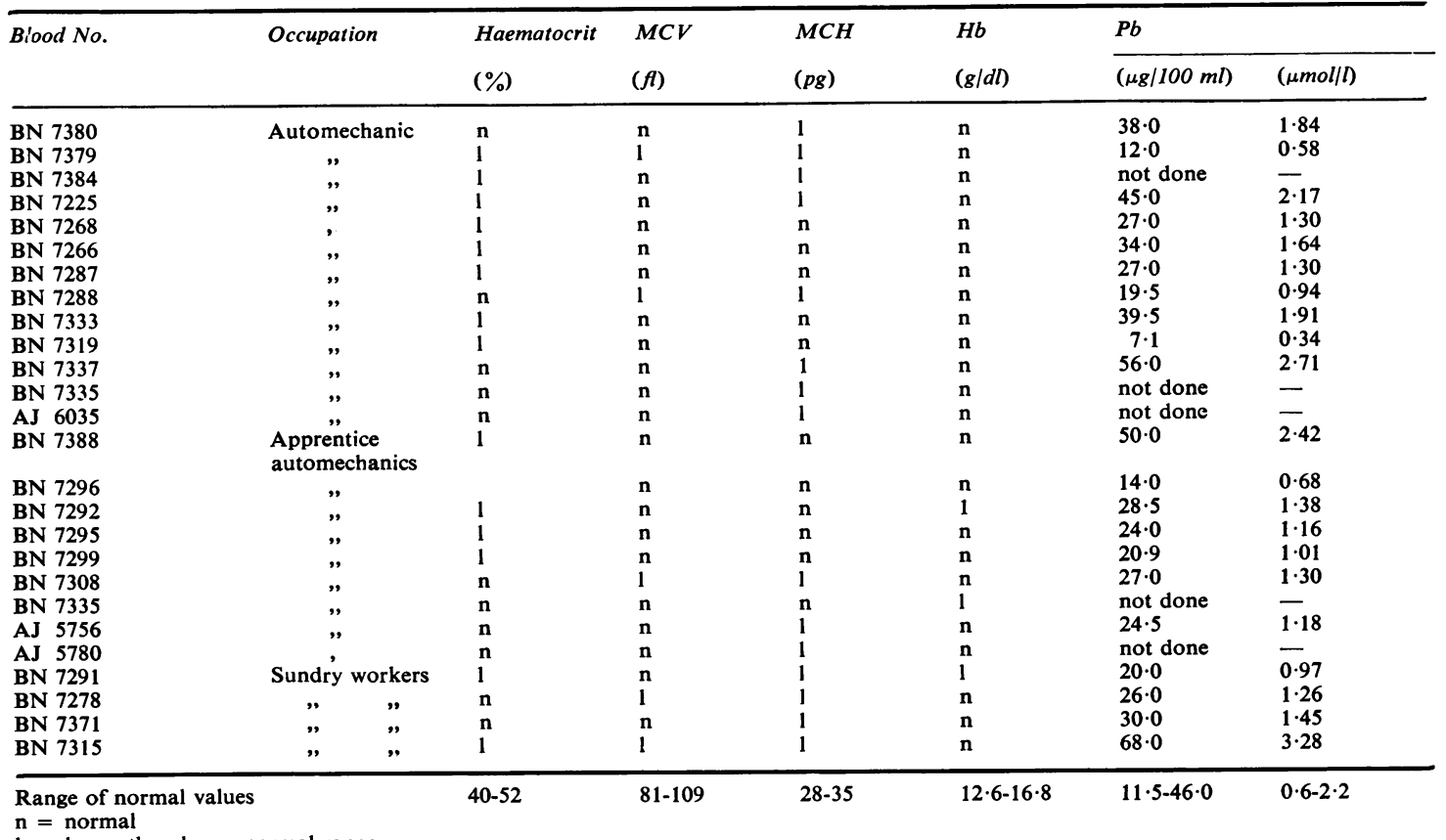

$\mathrm{n}=$ normal

$1=$ lower than lower normal range

Table 6 Occurrence of subjective symptoms among autoworkshop workers

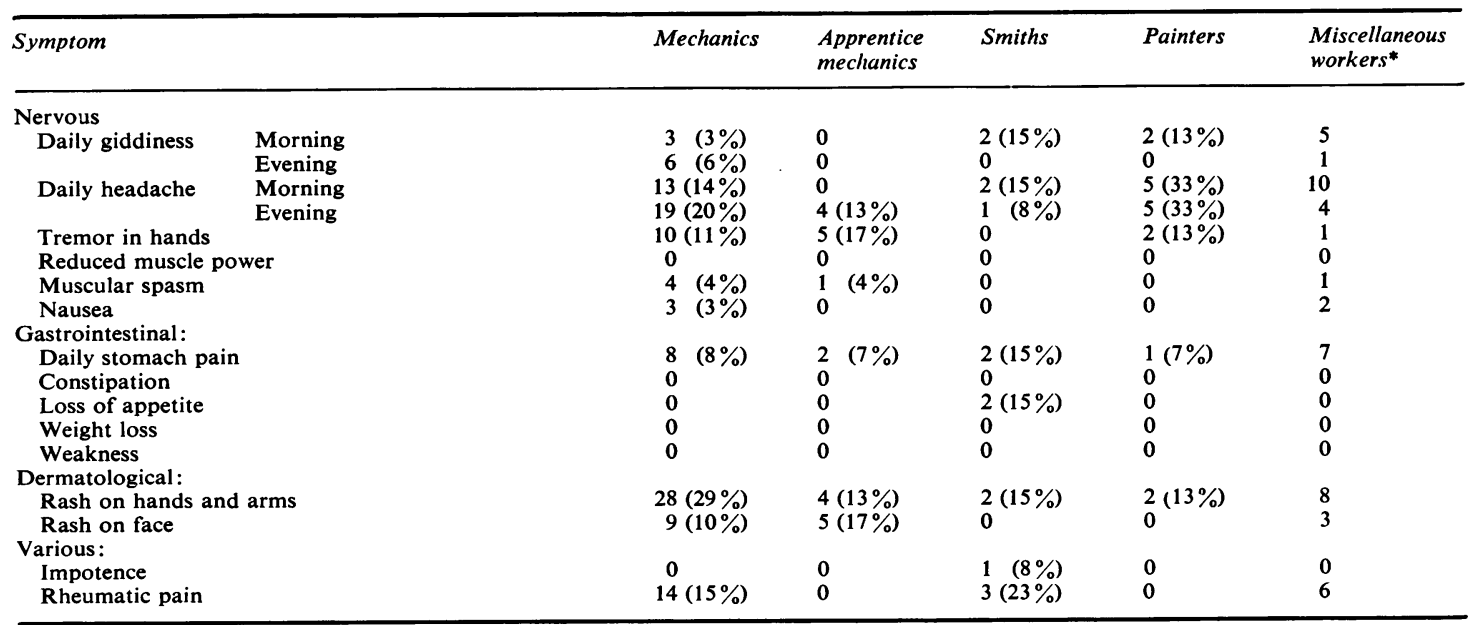

* Percentages not shown because of diversity of workers in this group

mechanics with high blood lead levels showed Discussion

altered AlT and AsT levels respectively.

No other signs of lead poisoning such as reticulocytosis and increased basophil cells in the peripheral blood were observed. There was no lead deposition in the gum margins in the mouth.

The risk factors for employees in autoworkshops depend upon the site and type of work. Potential sources of lead pollution are automobile exhaust gas, welding, and lead-containing grease and petrol 
Table 7 Relationship between blood lead level, skin rash and serum transaminase activity in automechanics

\begin{tabular}{|c|c|c|c|c|c|c|c|}
\hline \multirow[t]{2}{*}{ Workshop $†$} & \multicolumn{2}{|l|}{ Blood lead } & \multirow[t]{2}{*}{ Skin rash } & \multirow[t]{2}{*}{ Hand tremor } & \multirow{2}{*}{$\begin{array}{l}\text { Digital } \\
\text { paraesthaesia }\end{array}$} & \multicolumn{2}{|c|}{ Serum transaminases } \\
\hline & $(\mu \mathrm{g} / 100 \mathrm{ml})$ & $(\mu \mathrm{mol} / \mathrm{l})$ & & & & $A s T$ & $A l T$ \\
\hline \multirow[t]{8}{*}{ I } & 81.5 & 3.94 & & & & $\mathbf{n}$ & * \\
\hline & $78 \cdot 0$ & $3 \cdot 77$ & $x$ & & & $\mathbf{n}$ & $\mathbf{n}$ \\
\hline & 53.0 & 2.56 & & $x$ & & $\mathbf{n}$ & $\mathbf{n}$ \\
\hline & $45 \cdot 0$ & $2 \cdot 17$ & & & & $\mathbf{n}$ & $\mathbf{n}$ \\
\hline & $48 \cdot 0$ & $2 \cdot 32$ & & & $x$ & $\mathbf{n}$ & $\mathbf{n}$ \\
\hline & $66 \cdot 0$ & $3 \cdot 19$ & & & & $\mathbf{n}$ & n \\
\hline & $60 \cdot 0$ & 2.90 & $x$ & $x$ & & $\mathbf{n}$ & * \\
\hline & 83.0 & 4.01 & & & & $\mathbf{n}$ & $\mathbf{n}$ \\
\hline \multirow[t]{8}{*}{ II } & $91 \cdot 0$ & $4 \cdot 40$ & $x$ & & $x$ & $\mathbf{n}$ & $\mathbf{n}$ \\
\hline & $125 \cdot 0$ & 6.04 & $x$ & & & $\mathbf{n}$ & * \\
\hline & $80 \cdot 0$ & $3 \cdot 86$ & & & & $\mathbf{n}$ & $\mathbf{n}$ \\
\hline & $43 \cdot 0$ & $2 \cdot 08$ & $x$ & & & $\mathbf{n}$ & $\mathbf{n}$ \\
\hline & $52 \cdot 0$ & $2 \cdot 51$ & $x$ & & & $\mathbf{n}$ & $\mathbf{n}$ \\
\hline & $72 \cdot 0$ & $3 \cdot 48$ & $x$ & & & $\mathbf{n}$ & $\mathbf{n}$ \\
\hline & $44 \cdot 0$ & $2 \cdot 13$ & $x$ & & & $\mathbf{n}$ & $\mathbf{n}$ \\
\hline & $45 \cdot 0$ & $2 \cdot 17$ & $x$ & & & $\mathbf{n}$ & $\mathbf{n}$ \\
\hline \multirow[t]{4}{*}{ IV } & $43 \cdot 5$ & $2 \cdot 10$ & $x$ & $x \times$ & & $\mathbf{n}$ & $\mathbf{n}$ \\
\hline & $51 \cdot 5$ & $2 \cdot 49$ & $x$ & & & $\mathbf{n}$ & $\mathbf{n}$ \\
\hline & $47 \cdot 5$ & $2 \cdot 29$ & $x$ & & & $\mathbf{n}$ & $\mathbf{n}$ \\
\hline & $56 \cdot 0$ & $2 \cdot 71$ & $x$ & & & $\mathbf{n}$ & $\mathbf{n}$ \\
\hline \multirow[t]{5}{*}{$\mathbf{v}$} & $70 \cdot 0$ & $3 \cdot 38$ & $x$ & & & $\mathbf{n}$ & $\mathbf{n}$ \\
\hline & $56 \cdot 0$ & $2 \cdot 71$ & $\times$ & & & $\mathrm{n}$ & $\mathbf{n}$ \\
\hline & $62 \cdot 5$ & 3.02 & & & & $\mathbf{n}$ & $\mathbf{n}$ \\
\hline & $56 \cdot 0$ & $2 \cdot 71$ & $x$ & & & $\mathbf{n}$ & $\mathbf{n}$ \\
\hline & $77 \cdot 0$ & $3 \cdot 72$ & & & & $\mathbf{n}$ & $\mathbf{n}$ \\
\hline \multirow[t]{5}{*}{ VI } & $49 \cdot 5$ & $2 \cdot 39$ & & & & $\mathbf{n}$ & $\mathbf{n}$ \\
\hline & not done & & & & & * & * \\
\hline & not done & & & & & $\mathbf{n}$ & * \\
\hline & $53 \cdot 6$ & $2 \cdot 59$ & & & & $\mathbf{n}$ & $\mathbf{n}$ \\
\hline & $61 \cdot 0$ & $2 \cdot 95$ & & & & $\mathbf{n}$ & $\mathbf{n}$ \\
\hline \multirow[t]{8}{*}{ VII } & $54 \cdot 0$ & 2.61 & $x$ & & $x$ & $\mathbf{n}$ & $\mathbf{n}$ \\
\hline & $41 \cdot 0$ & 1.98 & & & & $\mathbf{n}$ & $\mathrm{n}$ \\
\hline & $89 \cdot 0$ & $4 \cdot 23$ & & & $x$ & $\mathbf{n}$ & $\mathbf{n}$ \\
\hline & $52 \cdot 5$ & $2 \cdot 54$ & & & & $\mathbf{n}$ & $\mathbf{n}$ \\
\hline & $68 \cdot 0$ & $3 \cdot 28$ & $x$ & & & $\mathbf{n}$ & $\mathbf{n}$ \\
\hline & $56 \cdot 5$ & $2 \cdot 73$ & & & & $\mathbf{n}$ & $\mathbf{n}$ \\
\hline & $45 \cdot 0$ & $2 \cdot 14$ & & & & $\mathbf{n}$ & $\mathbf{n}$ \\
\hline & $49 \cdot 5$ & $2 \cdot 39$ & & & & $\mathbf{n}$ & $\mathbf{n}$ \\
\hline \multirow[t]{5}{*}{ VIII } & $57 \cdot 5$ & $2 \cdot 78$ & & & sometimes & $\mathbf{n}$ & $\mathbf{n}$ \\
\hline & $48 \cdot 5$ & $2 \cdot 34$ & & & & $\mathrm{n}$ & * \\
\hline & 63.0 & 3.04 & $x$ & $x$ & & $\mathbf{n}$ & $\mathbf{n}$ \\
\hline & $83 \cdot 0$ & 4.01 & $x$ & $x$ & & $\mathbf{n}$ & $\mathbf{n}$ \\
\hline & $50 \cdot 0$ & $2 \cdot 42$ & $x$ & & & $\mathbf{n}$ & $\mathbf{n}$ \\
\hline $\mathbf{X}$ & $45 \cdot 0$ & $2 \cdot 17$ & & & & $\mathrm{n}$ & $\mathbf{n}$ \\
\hline
\end{tabular}

$\dagger ;$ workers in workshops III and IX had normal blood lead levels

$x=$ sign is present

$\mathbf{n}=$ normal

* = high

$A I T=$ alanine aminotransferase $(G P T)$

$A s T=$ aspartate aminotransferase (GOT)

penetrating the skin. In eight out of ten workshops autoworkers were found to have blood lead levels significantly higher than the mean for controls. Overall, $59 \%$ of the autoworkers had a mean blood lead level higher than the mean of the control subjects. Nine per cent of the autoworkers were found to have a blood lead level above the acceptable limit of $80 \mu \mathrm{g} / 100 \mathrm{ml}, 3.86 \mu \mathrm{mol} / 1$ (Kehoe, 1971). Garage mechanics have previously been shown to have a mean blood lead level of $38 \mu \mathrm{g} / 100 \mathrm{ml}$, $1.84 \mu \mathrm{mol} / 1$ (Hammond, 1969), which is in close agreement with our data.

Airborne particles of over $1.5 \mu$ in diameter were collected on filters and represent a major portion of particulate lead pollution due to motor

exhausts (Nozaki, 1966; Stankovic, 1971).

The lead content of air samples collected outside the workshops was much less than that of the air in various rooms (Table 3). Nevertheless the lead pollution of the workshop air could not alone explain the high blood lead levels observed among autoworkers. Assuming that the airborne lead is maximally $5 \mu \mathrm{g} / \mathrm{m}^{3}$ in the workshop, according to Blokker (1970) a worker will inhale about $34 \mu \mathrm{g}$ lead/day, of which $40 \%$ will be absorbed. All other factors being constant, this will give a $100 \%$ rise in the blood lead values compared to the normals (approx. $40 \mu \mathrm{g} / 100 \mathrm{ml}, 1.93 \mu \mathrm{mol} / \mathrm{l}$ ). However, the blood lead level in many mechanics exceeded $40 \mu \mathrm{g} / 100 \mathrm{ml}$. An indirect method of evaluating 
blood lead levels in mechanics would be the application of Danielson's formula (1967) which relates lead in whole blood to lead absorbed over a 24-hour period. In order to reach a whole blood lead level of $50 \mu \mathrm{g} / 100 \mathrm{ml}(2.42 \mu \mathrm{mol} / 1)$, the lead intake per day will be $150 \mu \mathrm{g}$. Assuming that the tidal air is $500 \mathrm{ml}$ air, $150 \mathrm{ml}$ of which is the dead space, and that respiration occurs 20 times a minute during an eight-hour period of work, the intake will be approximately $0.35 \times 20 \times 60 \times 8=33701$ air, or $3.37 \mathrm{~m}^{3}$. Thus, with a blood lead level of $50 \mu \mathrm{g} / 100 \mathrm{ml}$ $(2.42 \mu \mathrm{mol} / \mathrm{l})$, the working room air should contain approximately $45 \mu \mathrm{g} / \mathrm{m}^{3}$ lead, which is higher than the levels found in the present study. It is therefore reasonable to assume that high blood lead levels among the mechanics are not due to airborne lead alone. Among other potential sources, organic lead derivatives which are added to petrol as anti-knock agents (tri- and tetraethyl lead) or to lubricating oils and greases (lead naphthenate) may be considered. Lack of sufficient protection might allow organic lead to be taken up by the body through direct skin contact. Inadequate protection of workers cleaning storage tanks in which leaded fuel had been stored, resulted in high blood lead levels (Beattie et al., 1972). Among workers using tetraethyl lead, $60 \%$ have been shown to have blood lead levels of $30-50 \mu \mathrm{g} / 100 \mathrm{ml}(1 \cdot 45-2 \cdot 42 \mu \mathrm{mol} / \mathrm{l})$ (Robinson, 1976). Lead naphthenate may be absorbed through the skin giving rise to high lead values in workers who are using lubricants and greases, and gear oils (Van Peteghem and De Vos, 1974). Cutaneous application of lead naphthenate solution has been found to produce chronic lead toxicity in rats (Rastogi et al., 1976). In the present investigation, high levels of blood lead (mean $57.4 \mu \mathrm{g} / 100 \mathrm{ml}$, $2.77 \mu \mathrm{mol} / \mathrm{l}$ ) were found in mechanics, especially in the workshops where diesel engines were repaired. Thus a rash on the arms of $29 \%$ of mechanics, due to the defatting effect of mineral oil and petrol may in part give rise to lead absorption from petrol, lubricants and greases. Workers in one of the shops admitted that lubricants containing lead naphthenate were used for cleaning hands. These oils effectively removed carbon particles probably due to their detergent content. In none of the workshops was any mention made of the risk incurred in using these oils.

A significant correlation between an increase in blood lead levels and ALAD activity was found in the present study. The blood lead levels in control subjects were found to be in agreement with the findings in a normal Danish and Swedish population (Grandjean, 1973; Haeger-Aronsen et al., 1974) and the higher lead values with lower ALAD activity in blood were parallel to those values found by
Haeger-Aronsen et al., (1974) among accumulator workers. Our data also confirm that a low ALAD activity is a sensitive indicator of lead absorption. We were unable to confirm the theory advanced by Kehoe (1971) that the determination of ALAD activity was not a positive indicator of lead exposure.

Table 8 shows the validity of the correlation between ALAD activity and the lead level in whole blood calculated according to Zielhuis and Verberk (1974). It is evident that at all the chosen limit values,

Table 8 Relationship between increased lead level and depressed $A L A D$ activity in whole blood*

\begin{tabular}{llll}
\hline & \multicolumn{3}{l}{ Lead level } \\
\cline { 2 - 4 } & $>40 \mu \mathrm{g} \%$ & $>60 \mu \mathrm{g} \%$ & $>80 \mu \mathrm{g} \%$ \\
& $(1.93 \mu \mathrm{mol} / \mathrm{l})$ & $(2.9 \mu \mathrm{mol} / \mathrm{l})$ & $(3.86 \mu \mathrm{mol} / \mathrm{l})$ \\
\hline Sensitivity & 1.00 & 0.75 & 0.33 \\
Specificity & 0.63 & 0.91 & 0.96 \\
Validity & 1.63 & 1.66 & 1.29 \\
\hline
\end{tabular}

*Zielhuis and Verberk, 1974.

validity $=$ sensitivity + specificity $>1$, meaning that a positive correlation exists between the two functions. It can be noticed that at the limit value of $80 \mu \mathrm{g} / 100 \mathrm{ml}(3.86 \mu \mathrm{mol} / \mathrm{l})$ (Kehoe, 1965) high specificity and low sensitivity are revealed. Thus ALAD activity in blood is a more relevant marker for blood lead levels at the limits 40 or $60 \mu \mathrm{g} / 100 \mathrm{ml}(1.93-2.90 \mu \mathrm{mol} / \mathrm{l})$ compared to $80 \mu \mathrm{g} / 100 \mathrm{ml}(3.86 \mu \mathrm{mol} / \mathrm{l})$. The validity of selecting the following limits: $40 \mu \mathrm{g} / 100 \mathrm{ml}(1.93 \mu \mathrm{mol} / \mathrm{l})$ lead and $50 \%$ decrease in ALAD activity as differential limits for intoxication is similar to that described by Zielhuis and Verberk (1974).

None of the workers showed any signs of anaemia similar to those found by McCallum et al. (1968) in workers in shipbreaking yards. Kehoe (1965) mentioned that no clinical symptoms were seen below blood lead levels of $80 \mu \mathrm{g} / 100 \mathrm{ml}$ and this is in agreement with the present study.

There is a relatively low incidence of rheumatic compaints $(15 \%)$ among the workers. Complaints related to the central nervous system may be due to heavy lead load (Carson et al., 1974), possibly as a result of working with organic lead derivatives (Frost and Myschetzky, 1969); Lansdown et al., 1974; Konat and Clausen, 1974; Melgaard et al., 1976a and b). However, dizziness and headaches may also be due to organic solvents such as hexane. It is not possible to interpret more fully the significance of hypertension among $37 \%$ of the people interviewed in the present study without a closer clinical investigation. The percentage of hypertension was comparatively high among the young workers, as Hagerup (1974) found hyper- 
tension in a normal Danish population in only $21 \%$ of the individuals studied.

We wish to express our gratitude to the Commission of the European Communities, whose grant no. 075/74/ENV.DK from the Environmental Research Fund made it possible to carry out these studies. We also wish to thank Mr. Erik Østergaard for his skilful technical assistance, the Danish Medical Council and Odense University for financial support in making available the atomic absorption apparatus used and the Danish International Development Agency (DANIDA), whose grant of a research scholarship (D4 JNR 104 P3 Ind 408) made it possible for S. C. Rastogi to perform this work.

\section{References}

Barltrop, D. (1969). Environmental lead and its paediatric significance. Postgraduate Medical Journal, 45, 129-134.

Beattie, A. D., Moore, M. R., and Goldberg, A. (1972). Tetraethyl lead poisoning. Lancet, 2, 12-15.

Blokker, P. C. (1970). Literature survey of the health aspects of lead emission from gasoline engines. Report No. 24/70. Stichting CMC: The Hague.

California Department of Public Health (1967). Division of Environmental Sanitation and Division of Laboratories. Lead in the environment and its effect on humans. Berkelly, California.

Carson, T. L., Van Gelder, G. A.. Karas, G. C., and Buck, W. B. (1974). Slowed learning in lambs prenatally exposed to lead. Archives of Environmental Health, 29, 154-156.

Danielson, L. (1967). Gasoline containing lead. Bulletin No. 6, Swedish Natural Science Research Council, Ecological Research Committee Stockholm.

de Bruin, A. (1971). Certain biological effects of lead upon the animal organism. Archives of Environmental Health, 23, 249-264.

Documenta Geigy (1962). Scientific Tables, 6th edition, pp. 180-191 Geigy: Basel.

Frost, J. and Myschetzky, A. (1969). In Forgiftninger I: Medicinsk Kompendium, vol. II, p. 1166. Edited by M. Iversen, J. C. Jacobsen, K. Kjerulf, and J. Hess Taysen. Nyt Nordisk Forlag Arnold Busck: Copenhagen.

Goyer, R. A. (1971). Lead toxicity: a problem in environment. American Journal of Pathology, 64, 167-179.

Goyer, R. A., and Phyne, B. C. (1973). Pathological effects of lead. International Reviews of Experimental Pathology, 12, 1-77.

Grandjean, P. (1973). Bly $i$ danskere. Trykteknik A/S: Copenhagen.

Habibi, K. (1970). Characterisation of particulate lead in vehicle exhaust-experimental techniques. Environmental Science and Technology, 4, 239-253.

Haeger-Aronsen, B., Abdulla, M., and Fristedt, B. I. (1974). Effect of lead on delta-aminolevulinic acid dehydratase activity in red blood cells. Archives of Environmental Health, 29, 150-153.

Hagerup, L. M. (1974). Coronary heart disease risk factors in men and women. Acta Medica Scandinavica, Suppl. No. 557.
Hammond, P. B. (1969). Lead poisoning: an old problem with new dimensions. Essays in Toxicology, 1, 115-155.

Hicks, R. M. (1972). Air-borne lead as an environmental toxin. Chemical-Biological Interactions, 5, 361-390.

Lead in the Environment Institute of Petroleum (1972). Edited by P. Hepple. Applied Science Publishers: Barking, England.

Kehoe, R. A. (1965). Contaminated and natural lead environments of man. Archives of Environmental Health, 11, 736-739.

Kehoe, R. A. (1971). Standards for the prevention of occupational lead poisoning. Archives of Environmental Health, 23, 245-248.

Konat, G., and Clausen, J. (1974). The effect of long-term administration of triethyllead on the developing rat brain. Environmental Physiology and Biochemistry, 4, 236-242.

Lansdown, R. G., Clayton, B. E., Graham, P. J., Shepherd, J., Delves, H. T., and Turner, W. C. (1974). Blood-lead levels, behaviour and intelligence, a population study. Lancet, 1, 538-541.

Ludwig, J. H, Diggs, D. R., Hesselberg, H. E., and Maga, J. A. (1965). Survey of lead in the atmosphere of three urban communities. American Industrial Hygiene Association Journal, 26, 270-284.

McCallum, R. I., Sanderson, J. T., and Richards, A. E. (1968). The lead hazard in shipbreaking: the prevalence of anaemia in burners. Annals of Occupational Hygiene, 11, 101-113.

Melgaard, B., Clausen, J., and Rastogi, S. C. (1976a). Heavy metal levels and delta-amino-levulinic acid dehydrase levels in peripheral polyneuropathy. Acta Neurologica Scandinavica, 53, 291-307.

Melgaard, B., Clausen, J., and Rastogi, S. C. (1976b). Abnormalities in peripheral nerves of automechanics with increased heavy metal levels. Acta Neurologica Scandinavica, 54, 227-240.

Nozaki, K. (1966). Methods for studies on inhaled particles in human respiratory system and retention of lead fume. Industrial Health, 4, 118-128.

Rastogi, S. C., Clausen, J., and Srivastava, K. C. (1976). Selenium and lead: mutual detoxifying effects. Toxicology, 6, 277-288.

Robinson, T. R. (1976). The health of long service tetraethyllead workers. Journal of Occupational Medicine, 18, 31-40.

Schroeder, H. A., and Tipton, I. H. (1968). The human body burden of lead. Archives of Environmental Health, 18, 965-978.

Stankovic, M. K. (1971). Biochemical tests for the appraisal of exposure lead. Archives of Environmental Health, 23, 265-269.

Thomas, H. V., Milmore, B. K., Heidbreder, G. A., and Kogan, B. A. (1967). Blood lead of persons living near freeways. Archives of Environmental Health, 15, 695-702.

van Peteghem, T. and de Vos, H. (1974). Toxicity study of lead naphthenate. British Journal of Industrial Medicine, 31, 233-238.

World Health Organization (1962). Arterial hypertension and ischaemic heart disease. Technical Report Series No. $231 ;$ p. 7.

Zielhuis, R. L., and Verberk, M. M. (1974). Validity of biological tests in epidemiological toxicology. Internationales Archiv für Arbeitsmedizin, 32, 167-190. 